\title{
KEEPING UP WITH THE COMMON LAW O'SULLIVANS? THE LIMITS OF COMPARATIVE LAW IN THE CONTEXT OF MILITARY JUSTICE LAW REFORMS
}

\author{
MIKE MADDEN*
}

Critics of the Canadian military justice system have recently suggested that Canada should follow developments in military law that have taken place in Ireland, particularly with respect to the expansive procedural rights that are now afforded to accused persons who face summary forms of trial within the Irish system. This article demonstrates that these calls for comparative-based law reform fail to appreciate important differences in the Irish and Canadian environments within which the respective military justice systems operate, specifically through a case study that discusses the distinct international human rights law obligations that bind the two states, and the unique labour climates within the two armed forces. Ultimately, after illustrating how comparative law alone cannot provide a compelling rationale for military justice law reforms in Canada, the article refers to the Irish/Canadian case study in order to argue that knowledge of comparative law is perhaps more useful to responsible scholars in order to deconstruct law reform proposals rather than to generate new law reform ideas.
Les critiques du système de justice militaire canadien ont récemment laissé entendre que le Canada devrait suivre les développements du droit militaire de l'Irlande, tout particulièrement en ce qui concerne les droits procéduraux expansifs qui sont maintenant accordés aux accusés devant subir des formes de procès sommaires dans le système irlandais. L'article démontre que l'appel à une réforme du droit de manière comparative n'a pas tenu compte des différences importantes des environnements irlandais et canadiens au sein desquels les systèmes de justice militaire respectifs fonctionnent, tout particulièrement au moyen d'une étude cas portant sur les obligations spécifiques des droits internationaux de la personne liant les deux États ainsi que le climat de travail unique aux sein des deux forces armées. En définitive, après avoir illustré de quelle manière le droit comparé, en soi, ne peut constituer une raison impérieuse de réforme du droit militaire au Canada, l'article fait référence à l'étude cas irlandaise et canadienne pour faire valoir que la connaissance du droit comparé s'avère peut-être plus utile pour les érudits responsables de déconstruire des propositions de réforme judiciaire au lieu de produire de nouvelles idées de réforme.

\section{TABLE OF CONTENTS}

I. INTRODUCTION . . . . . . . . . . . . . . . . . . . . . . . . . . . . . . . . . . . 126

II. UNDERSTANDING CANADIAN AND

IRISH MilitARY JUSTICE SySTEMS $\ldots \ldots \ldots \ldots \ldots \ldots$

A. The Canadian Military Justice System . . . . . . . . . . . 129

B. The Irish Military Justice SyStem $\ldots \ldots \ldots \ldots \ldots \ldots$

III. UNDERSTANDING WHY CANADIAN AND

IRISH MilitARy Justice SySTEMS DifFER $\ldots \ldots \ldots \ldots \ldots \ldots$

A. INTERNATIONAL HUMAN RIGHTS INFLUENCES ON IRISH

AND CANADIAN MiLITARY JUSTICE . . . . . . . . . . . . . . . . 135

CD, BA, MA, LLB, PhD (candidate) Dalhousie University’s Schulich School of Law, Halifax, Canada. Legal Advisor, Office of the Judge Advocate General of the Canadian Forces. This article expands on a paper that was presented at the Fifth Annual Irish Society of Comparative Law Conference on 25 May 2013. The author wishes to thank Lieutenant-Colonel Steve Strickey and Major Ian Davis of the Canadian Armed Forces and Commandants Fintan McCarthy and Noel Conway of the Legal Services Branch of the Irish Defence Forces, who all provided valuable feedback on an earlier draft of this article. The opinions and views expressed in this article are solely those of the author acting in his personal capacity, and they are not intended to, and do not necessarily, reflect the views of the Government of Canada, the Canadian Forces, or the Office of the Judge Advocate General. 


\section{B. IRISH REPRESENTATIVE ASSOCIATIONS AND}

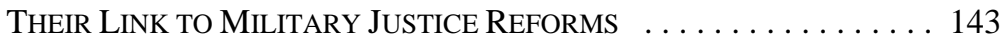

IV. RE-THINKING THE ROLE OF COMPARATIVE LAW

AS A LAW REFORM TOOL . . . . . . . . . . . . . . . . . . . . . . . 149

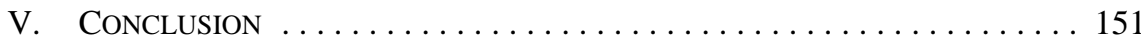

\section{INTRODUCTION}

The purpose of this article, simply stated, is to make two points — one specific, and one general in nature. Through a case study that considers recent and ongoing military justice developments in Ireland and Canada, this article argues that critical differences in the domestic and international politico-legal climates of the two countries render comparative study of their military justice systems problematic for law reform purposes. On a broader level, the Irish/Canadian case study also highlights some of the dangers inherent in using comparative law to transplant ${ }^{1}$ concepts from one jurisdiction to another when crafting domestic legislation. Ultimately, the article argues that the scholarly study of comparative law remains necessary in order to critique unprincipled calls for law reform that are based solely on legal developments in foreign jurisdictions.

The title of this article, and indeed the very idea underlying it, arise in response to a recent publication by Canadian scholars Christine Boyle and Emma Cunliffe entitled, "Right to Counsel During Custodial Interrogation in Canada: Not Keeping up With the Common Law Joneses."2 Boyle and Cunliffe compare developments in other common law jurisdictions with Canadian law and conclude that Canada has not kept up with its neighbours since there is no ongoing right to counsel during custodial interrogations in Canada even though such a right exists elsewhere. The authors suggest that a "tipping point" principle of constitutional interpretation should be adopted in Canada, such that courts could take remedial action in cases where "analysis of other common law jurisdictions and international aspirations shows that Canada has fallen behind in the protection of human rights." 3 Boyle and Cunliffe ultimately conclude that "Canada should keep up with the common law Joneses, where their laws have tipped in favour of enhanced human rights protection," 4 including protections such as a right to counsel during custodial interrogations.

This keeping-up-with-the-Joneses line of reasoning is superficially attractive: it appeals to one's schoolyard sense of how to behave conformingly in the face of peer pressure, and it stands out (from within a notoriously complicated mass of lengthy works of legal scholarship) ${ }^{5}$ as a simple, understandable approach to law reform. Perhaps for these reasons,

See John D Jackson, “The Effect of Human Rights on Evidentiary Processes: Towards Convergence, Divergence or Realignment?” (2005) 68:5 Mod L Rev 737 at 738-39 for a summary of literature describing and critiquing the effectiveness of legal transplants. 2 Christine Boyle \& Emma Cunliffe, "Right to Counsel During Custodial Interrogation in Canada: Not Human Rights: Reimagining Common Law Procedural Traditions (Oxford: Hart Publishing, 2012) 79. Ibid at 81 .

Ibid at 101 .

In response to feedback indicating that law review articles were generally too long and somewhat unreadable, the Harvard Law Review issued a "Joint statement regarding articles length" (2005), online: Harvard Law Review < http://www.harvardlawreview.org/PDF/articles_length_policy.pdf > in 2005 that was endorsed by ten other top law reviews. This document describes the perceived problem of excessively long articles, and communicates a strong message in favour of articles that are less than 70 pages in length. 
the keeping-up-with-the-Joneses rationale has been embraced by Michel Drapeau, a retired Canadian military officer and frequent commentator on military law matters, who argues that Canada is "falling further behind contemporary societal norms by failing to follow necessary evolutions of military justice taking place in many other common law jurisdictions such as the United Kingdom, Ireland, Australia and New Zealand.”6

However, criminal justice systems, and especially military justice systems, are borne of their own unique historical and contextual circumstances. These systems contain complex codes of procedure and, beyond a common core, wide variances in substantive criminal law. ${ }^{7}$ In this area of law, perhaps more than in any other area, “[a]ttempts to import 'foreign' solutions often lead to practices being 'translated' in a different way and this can lead to fragmentation and divergence," awareness of and sensitivity to the domestic and international contexts within which the rules of an individual military or criminal justice system operate are essential to scholars or legislators who propose to adopt elements of foreign law.

In developing the argument, by way of analyzing the Irish/Canadian case study which shows that comparative law often represents a danger to the principled development of domestic legislation, the sections of this article that follow briefly describe key aspects of the Irish and Canadian military justice systems and how they have evolved somewhat interactively with one another since the end of the Second World War in order to highlight both the connections and some of the significant differences between the two systems. Next, the article looks more broadly at certain important social, cultural, political, and legal factors that are present in Ireland and Canada and have created fundamentally distinct environments within which the respective military justice systems operate. Finally, once the differences between the Irish and Canadian military justice systems are understood in terms of the related differences in each of their broader home environments, it is possible to see how misplaced calls for comparative-based law reform between such distinctive jurisdictions can be. In other words, the present Irish/Canadian case study should help to demonstrate the dangers that accompany well-intentioned but weak proposals for legal transplants from one jurisdiction to another and the continued importance of developing expertise in comparative law to defend against such law reform proposals.

\section{UNDERSTANDING CANADIAN AND IRISH MILITARY JUSTICE SYSTEMS}

Many parallels can be drawn between the Irish and Canadian military justice systems that rely on courts martial and summary proceedings in order to maintain discipline within the respective armed forces: both systems were originally modelled on the British tradition, ${ }^{9}$ and

Michel W Drapeau, “Time to rebrand JAG as CF legal advisor” The Hill Times (4 March 2013) 13. In the United States, for instance, the Uniform Code of Military Justice, 47 USC tit $10 \S 914$, forbids both "dueling" and "having knowledge of a challenge sent or about to be sent" without promptly reporting the fact to a proper authority. No similar prohibition exists under the Canadian National Defence Act, RSC 1985, c N-5 [NDA].

Jackson, supra note 1 at 739 .

See generally R Arthur McDonald, Canada's Military Lawyers, (Ottawa: Office of the Judge Advocate General, 2002) at 1-73 (for a history of the evolution of Canadian military law from British origins through to 1950). See also, Minister for Defence, Willie O'Dea, Seanad Éireann, Opening Statement on the Defence (Amendment) (No 2) Bill 2006, Second Stage (1 March 2007), online: Houses of Oireachtas: 
both were based in laws that remained essentially unchanged from the post-World War II period (1950s) until undergoing extensive reforms around and following the turn of the twenty-first century. ${ }^{10}$ Furthermore, there is a history of comparative interaction between the two military justice systems. Provisions of the Irish Defence Act, $1954^{11}$ were "largely influenced by the Canadian and British systems then in place," ${ }^{\prime 2}$ and more recent amendments to the Irish law in $2007^{13}$ were also drafted after comparative study of the "Canadian, British, Australian and other common law systems." ${ }^{14}$ Likewise, in Canada, the Office of the Judge Advocate General of the Canadian Forces continues to study foreign military justice systems, including the Irish system, in order to provide sound advice to government about "responsible development and positive change" ${ }^{15}$ within the Canadian military justice system. Critics of the Canadian system also look to Ireland and suggest that where Ireland has "seen fit to change the [military] summary trial system, it begs the question: why is Canada lagging behind?”16

At first glance, it seems as if a cycle of Irish-Canadian comparative military justice law reform has existed for some time; Canada's 1950 National Defence Act (NDA) provided a model for the 1954 Irish Defence Act, and Canada's 1998 NDA reforms provided a starting point for Irish reforms in 2007. ${ }^{17}$ However, the most recent Irish reforms went beyond those that were in place in Canada by offering procedural rights to accused persons that were ostensibly more generous and liberal than their Canadian equivalents (which is explained in more detail in the following sections of this article).

A simplistic analysis might therefore suggest that Canada should now mirror changes to the Irish system as part of the ongoing comparative law reform cycle. In fact, this very

Dáil Eireann Debate <http://www.defence.ie/WebSite.nsf/Speech+ID/4BEA80D628B019FC8025727 B0040DF05?OpenDocument>, wherein the Irish Minister for Defence acknowledges the British roots of the country's defence legislation.

10 In Canada, the National Defence Act, SC 1950, c 43, was enacted in 1950, and remained essentially unchanged in terms of its disciplinary provisions until Bill C-25: An Act to Amend the National Defence Act, SC 1998, c 35 was enacted in 1998. Bill C-25 made significant structural changes to both courts martial and summary trials, largely in an effort to keep pace with evolving human rights norms set out in the Canadian Charter of Rights and Freedoms which was entrenched in the Canadian Constitution in 1982 (see David Goetz, Government of Canada, "Bill C-25 Backgrounder” (25 November 1998), online: <http://www.parl.gc.ca/About/Parliament/LegislativeSummaries/bills_ls.asp?ls=C25\&Parl=36 \&Ses=1>). In Ireland, the Defence Act, 1954, No 18 of 1954, was enacted on 13 May 1954. Although the Act was amended frequently during the latter half of the twentieth century, it was not until the Defence (Amendment) Act 2007, No 24 of 2007 [Defence Act, 2007], was enacted on 21 April 2007 that Irish military law saw major changes to its disciplinary provisions.

Defence Act, 1954, ibid.

O’Dea, supra note 9.

Defence (Amendment) Act 2007, supra note 10.

O’Dea, supra note 9.

JAG Strategic Objective \#2: "Lead proactive military justice oversight, responsible development and positive change.” The Office of the Judge Advocate General, "Department of National Justice: Reports on Plans and Priorities 2013-14” (2013), online: National Defence and the Canadian Armed Forces <http://www.forces.gc.ca/en/about-reports-pubs-report-plan-priorities/2013-other-office-judge-advocategeneral.page $>$.

16 Michel W Drapeau, House of Commons Standing Committee on National Defence Meeting, 40th Parl, 3rd Sess, No 50 (28 February 2011) at 2.

17 It should be noted that the Irish Defence Act, 1954 was also amended in 2011 by Defence (Amendment) Act 2011, No 17 of 2011, July 26, 2011. However, the 2011 amendments to the Irish Act were targeted reforms designed to expand the pool of candidates eligible for appointment as the Director of Military Prosecutions, and as Military Judge, among a few other minor reforms. The 2011 amendments did not inspire comparisons with the Canadian military justice system. 
proposition has been advanced several times in Canadian media ${ }^{18}$ and academic publications, ${ }^{19}$ in the House of Commons during debate about proposed changes to the $N D A,{ }^{20}$ and in evidence given by witnesses at hearings before the House of Commons Standing Committee on National Defence. ${ }^{21}$ However, after outlining the basic workings of the Irish and Canadian systems, and after examining the different contexts within which the two military justice systems operate, a more nuanced analysis reveals, specifically, that there are compelling reasons for Canada to avoid following Irish military law reforms, and that, more generally, references to comparative law should be viewed with caution when law reforms are being considered by domestic governments.

\section{A. The Canadian Military Justice System}

The Canadian military justice system draws its legislative authority from the Code of Service Discipline that forms Part III of the NDA, but it also has roots in the Canadian Constitution: section 11(f) of the Canadian Charter of Rights and Freedoms ${ }^{22}$ provides that "Any person charged with an offence has the right ... except in the case of an offence under military law tried before a military tribunal, to the benefit of trial by jury where the maximum punishment for the offence is imprisonment for five years or a more severe punishment."23 As the text of this Charter right demonstrates, it would be incorrect to suggest - as Gilles Létourneau, one of Canada's more prominent authorities on military law, has suggested ${ }^{24}$ that military personnel and civilians in Canada benefit from different constitutional rights, since the right that is provided for within section 11(f) of the Charter applies identically to

Michel W Drapeau, "Bill C-15: Strengthening the Military Justice System, More Questions than Answers," The Hill Times (23 July 2012) 14 [Drapeau, "More Questions”]: “Of note, the U.K., Australia, New Zealand, and Ireland, whose military justice systems resemble that of Canada's have seen fit to modify their summary trial system so as to provide a much, much fairer judicial process. Why then are our own sailors, soldiers and RCAF personnel deprived of such enlightened substantive and procedural changes?”

19 Gilles Létourneau, Introduction to Military Justice: An Overview of the Military Penal Justice System and its Evolution in Canada (Montreal: Wilson \& Lafleur ltée, 2012) at 39.

20 See for instance House of Commons Debates, 41st Parl, 1st Sess, No 143 (19 June 2012) at 9846 (Tarik Brahmi): "As was mentioned earlier, if Commonwealth countries, such as Ireland, Australia and New Zealand, have been able to make these legislative amendments, why should Canada still not be able to do so?” See also House of Commons Debates, 41st Parl, 1st Sess, No 193 (6 December 2012) at 12958 (Rathika Sitsabaiesan): "Britain, Australia, New Zealand and Ireland have all seen fit to change the summary trial process. Why is Canada lagging behind?” (among many other similar speeches). See for instance, Gilles Létourneau (Retired Judge of the Federal Court of Appeal and the Court Martial Appeal Court of Canada, as an Individual), House of Commons Standing Committee on National Defence Meeting, 41st Parl, 1st Sess, No 65 (11 February 2013) at 12:

Mr. Drapeau has alluded to the fact that changes have taken place in Ireland, Australia, New

Zealand, France, Belgium, Austria, the Czech Republic, Germany, Lithuania, and the

Netherlands, and despite the fact that the requirements of independence, impartiality, fairness, and justice are the same in Canada as they are in England - and if anything, they are more compelling here, because in Canada they are entrenched in the Constitution - our soldiers in uniform are still denied fair treatment at a summary trial.

22 Canadian Charter of Rights and Freedoms, Part I of the Constitution Act, 1982, being Schedule B to the Canada Act, 1982 (UK), 1982, c 11 [Charter]. The Charter is Canada’s constitutionally-entrenched bill of rights.

23 Ibid, s 11(f).

$24 \quad$ See Létourneau, supra note 19 at 17: "there is no doubt under Canadian military law that persons tried before service tribunals are deprived of some of the rights that a person prosecuted before a civil court enjoys.” This argument is flawed in the sense that military law (i.e.: ordinary statute law) cannot deprive individuals of their constitutional rights. In Canada's system of constitutional democracy, the constitution is "the supreme law," and any statute that is inconsistent with the constitution is of "no force or effect” (see section 52 of the Constitution Act, 1982, being Schedule B to the Canada Act, 1982 (UK), 1982, c 11). Thus, the inability of an individual to be tried by a jury under military law in Canada does not amount to a deprivation of a constitutional right, but, rather, represents the implementation of a very specific right found at section 11(f) of the Charter. 
military members and civilians: they both are entitled to the benefit of a jury trial when charged with certain objectively serious offences under civilian law, but neither is entitled to the benefit of a jury trial for less objectively serious offences under civilian law or for any offences under military law. However, while the rights contained within section 11(f) of the Charter apply equally to military and civilian personnel in Canada, the Charter does explicitly recognize that some procedural differences are necessary when dealing with offences under military law that are tried before service tribunals as opposed to offences under civilian criminal law that are tried in civilian courts.

Under military law, there are two types of service tribunals in Canada: courts martial and summary trials. ${ }^{25}$ Courts martial resemble civilian criminal trials in that they involve professional judges, ${ }^{26}$ prosecutors, ${ }^{27}$ and (unless an accused person does not desire the assistance of counsel) defence lawyers, ${ }^{28}$ adhere to formal rules of evidence, ${ }^{29}$ and can give rise to appeals to a higher court. ${ }^{30}$ However, courts martial are distinctly military in their overall atmosphere: the judge is a legally-trained officer in the Canadian Forces who is appointed with tenure as a military judge by the Governor in Council, ${ }^{31}$ the prosecutor is also a uniformed military lawyer who acts on behalf of the Director of Military Prosecutions, ${ }^{32}$ and the proceedings involve typical military formalities, such as saluting the military judge when he or she enters the court martial. ${ }^{33}$

Summary trials, in contrast, are proceedings that cannot easily be compared with civilian criminal trials. A summary trial is "intended as an expedient and fair means to deal with minor service offences at the unit level," 34 so that any breaches of discipline can be promptly addressed, and any offenders can be quickly returned to duty within their units. "The purpose of summary proceedings is to provide prompt but fair justice in respect of minor service offences and to contribute to the maintenance of military discipline and efficiency, in Canada and abroad, in time of peace or armed conflict.”35

This desire to realize fair and expedient justice can help to explain many of the procedural features of summary trials. For instance, the presiding officer at a summary trial is generally the Commanding Officer of the accused person ${ }^{36}$ or another officer within the accused

$25 \quad$ NDA, supra note 7, s 2 (definition of “service tribunal”).

Ibid, ss 167(1), 174.

Ibid, s 165.11 .

See ibid, ss 249.19, 249.21 for a description of the Director of Defence Counsel Services’ responsibility to provide representation to accused persons.

29 See ibid, s 181 regarding the requirement for courts martial to follow rules of evidence "established by regulations made by the Governor in Council.” See also Military Rules of Evidence, CRC, c 1049 — the rules that have, in fact, been established by regulations.

See generally Military Rules of Evidence, ibid, Part III, Division III (Judicial Notice).

NDA, supra note 7, s 165.21 .

Ibid, s 165.15.

National Defence, Court Martial Procedures: Guide for Participants and Members of the Public, (Ottawa: Office of the Chief Military Judge, 2012) at 2: "Everyone rises whenever the military judge or members of the court martial panel enter the courtroom, and the military members wearing headdress salute the court."

34 National Defence, Annual Report of the Judge Advocate General to the Minister of National Defence on the Administration of Justice in the Canadian Forces: A Review from 1 April 2009 to 31 March 2010, (Ottawa: Office of the Judge Advocate General, 2010) at 13.

35 National Defence, Queen's Regulations and Orders for the Canadian Forces (2008), online: $<$ http://www.admfincs.forces.gc.ca/gro-orf/vol-01/hv-vh/cha_01/26032009-06062012-eng.asp>, art $108.02[Q R \& O]$.

$36 \quad$ NDA, supra note 7 , s 163(1). 
person's chain of command. ${ }^{37}$ The accused person does not have a right to be represented by counsel at a summary trial. However, the presiding officer has the discretion to allow the accused person to be represented by counsel, ${ }^{38}$ and the accused person will, in any event, be assisted throughout the trial process by an Assisting Officer who is appointed by the Commanding Officer. ${ }^{39}$ There is no prosecutor at a summary trial; instead, the presiding officer performs a function akin to an inquisitorial judge in the civil law tradition by actively seeking to discover all of the facts of the case (both incriminating and exculpatory) during a trial. ${ }^{40}$ The formal rules of evidence applicable at courts martial do not apply at summary trials. ${ }^{41}$ There is no right to appeal a summary trial decision to a higher court, although an accused person can request that the decision be reviewed by the presiding officer's superior in matters of discipline - a more senior, but non-judicial officer in the offender's chain of command. ${ }^{42}$ As the above description demonstrates, summary trials differ in many respects from an archetypal common law or adversarial criminal proceeding.

Although the procedure at summary trials is somewhat unique within the broad Canadian criminal law landscape, the consequences of a conviction at summary trial can be very similar to those that would follow from a criminal conviction in a civilian court. For instance, a Commanding Officer who presides at a summary trial can impose a punishment of up to 30 days of detention on an offender, ${ }^{43}$ to be served in a military detention barrack. ${ }^{44}$ Additionally, convictions for service offences under military law, including convictions rendered by summary trials, now always lead to the creation of criminal records that can only be suspended after the expiration of fixed periods of time and successful applications for record suspensions by the respective offenders. ${ }^{45}$ (However, this situation will change when legislation that was recently enacted comes into force). ${ }^{46}$ Thus, there are recognizable elements of criminal law within Canada's military justice system, both at courts martial and at summary trials.

Generally speaking, however, the most serious offences under military law (including offences such as negligent performance of a military duty and desertion) can only be tried by courts martial. ${ }^{47}$ Furthermore, in any other less serious case where there is nonetheless a possibility of detention being imposed as a sentence, an accused person will be offered an election (or choice) to be tried by court martial instead of summary trial. ${ }^{48}$ Finally, even if an accused person does not elect to be tried by court martial, a summary trial presiding

Ibid, s 163(4) (referring to delegated officers), and s 164(1) (referring to superior commanders). $Q R \& O$, supra note 35, art 108.14, Note B.

Ibid, arts 108.14(1)-(5).

Ibid, art 108.21(2).

Ibid, art 108.21(1).

Ibid, art 108.45.

NDA, supra note 7, s 163(3)(a).

Ibid, s 220(4).

See Criminal Records Act, RSC 1985, c C-47, s 4(1) for the times before which an individual convicted of a service offence under the NDA can apply for a criminal record suspension. This situation can be contrasted with the law in Ireland, where there is no provision for the creation of a criminal record after a charge has been proven through the summary disposal process or after a conviction by a court-martial. See Bill C-15, An Act to amend the National Defence Act and to make consequential Amendments to Other Acts, SC 2013, c 24, s 75. This provision would deem many offences under the NDA not to be "offences" for the purposes of the Criminal Records Act (ibid).

The list of offences that can be tried by summary trial is found at $Q R \& O$, supra note 35, art 108.07; any offence that is not listed therein can only be tried by court-martial.

Ibid, art 108.17. 
officer can apply to have a matter disposed of by court martial if, for instance, the presiding officer feels that the charges are too complex or too serious to be tried at summary trial. ${ }^{49}$ In this respect, the heightened level of procedural protections that courts martial offer are widely, but not universally, available to those who are charged under the Code of Service Discipline.

The above description of Canada's military justice system has focused heavily on summary trials because these trials appear to be most frequently the subject of comparativebased law reform discussions. ${ }^{50}$ Perhaps the focus on summary trials can be explained by the fact that the constitutionality of trials by court martial has been considered several times by the Court Martial Appeal Court and the Supreme Court of Canada over the last three decades. ${ }^{51}$ As a result of these decisions, changes to certain features of courts martial, and to the institutional protections that are afforded to the military judges who preside at courts martial, have been enacted. ${ }^{52}$ With the advent of these changes, even Létourneau — one of Canada's most vocal critics of the military justice system — has proclaimed that

\footnotetext{
[m]ilitary judges have now acquired the last missing component of their judicial independence. They are appointed during good behaviour and their retirement is set at age $60 \ldots .$. [M]ilitary judges were able to secure the guarantees of judicial independence necessary to the exercise of a jurisdiction in criminal law akin to provincial courts and superior courts of criminal jurisdiction. ${ }^{53}$
}

In other words, there is now little debate about the fairness or constitutionality of trials by courts martial in Canada, but debate about the fairness of summary trials is still rather active. ${ }^{54}$ In recognition of this situation, the present Irish/Canadian military justice case study will concentrate on Canadian summary trials and their Irish equivalents after a brief overview of the Irish military justice system as a whole.

\section{B. THE IRISH MiLitARY JUSTICE SysteM}

The Irish military justice system can trace its authority to a constitutional source even more explicitly than the Canadian system. Article 38(4)(1) of the Irish Constitution provides that "military tribunals may be established for the trial of offences against military law alleged to have been committed by persons while subject to military law and also to deal with a state of war or armed rebellion. "55 Perhaps more remarkably, article 38(6) exempts military tribunals from compliance with articles 34 and 35 of the Constitution, ${ }^{56}$ and article 35(2) represents the constitutional provision that guarantees the independence of the judiciary in

$49 \quad$ Ibid, arts 108.16(1)(a)(iv)-(v).

See for instance, Drapeau, "More Questions," supra note 18.

See for instance, $R$ v Généreux, [1992] 1 SCR 259 [Généreux]; $R v$ Trépanier, 2008 CMAC 3; $R v$ Leblanc, 2011 CMAC 2.

52 See for instance, Bill C-60, An Act to Amend the National Defence Act (Court Martial) and to Make a Consequential Amendment to Another Act, SC 2008, c 29 (amending the NDA to allow the accused to choose whether to be tried by a General Court Martial with a panel or a Standing Court Martial with a judge sitting alone, in most circumstances).

Létourneau, supra note 19 at 47.

See House of Commons Debates, supra note 20.

Constitution of Ireland, 1 July 1937, as amended, art 38(4)(1).

Ibid, art 38(6): "The provisions of Articles 34 and 35 of this Constitution shall not apply to any court or tribunal set up under section 3 or section 4 of this Article." 
Ireland. ${ }^{57}$ In other words, as a matter of domestic constitutional law, there is no requirement that military judges or other officers who adjudicate charges under military law be "independent" in the judicial sense of the word. However, as will be discussed in detail below, Ireland's treaty obligations would seem to require such independence as a matter of international law. ${ }^{58}$

A comprehensive statutory code of military discipline is set forth at Part V of the Irish Defence Act, $1954 .{ }^{59}$ As in Canada, there are two forums through which charges can be tried in Ireland: summary disposal by a non-judicial officer and courts-martial. Again, as in Canada, courts-martial resemble civilian criminal courts to a significant extent in terms of the procedural protections that they offer to accused persons, while charges that are disposed of summarily represent a somewhat unique form of quasi-criminal or disciplinary procedure.

There are three types of courts martial in Ireland: Summary Court-Martial (SCM), Limited Court-Martial (LCM), and General Court-Martial (GCM). A SCM consists of a military judge (who is statutorily "independent in the performance of his judicial functions" 60 and who can only be removed from office by the President for stated reasons, after a highly formalized process has been followed ${ }^{61}$ sitting alone, and deciding all questions of law and fact. A SCM has jurisdiction to try lower-ranked individuals on less serious charges and can impose a maximum sentence of six months imprisonment. ${ }^{62}$ Limited and General CourtsMartial, in contrast, involve "Boards" of fact-finders drawn from the Defence Forces, ${ }^{63}$ and a finding of guilty on any charge must be decided by a two-thirds majority of the board members. ${ }^{64}$ A military judge presiding at a Limited or General Court-Martial decides questions of law, sums up the evidence, and determines the sentence. ${ }^{65}$ Like SCMs, LCMs also only have jurisdiction to try less serious offences, and lower-ranking individuals, but a LCM can impose any sentence up to imprisonment for a term of two years. ${ }^{66}$ A GCM is not limited in its jurisdiction to try offences under military law, in its jurisdiction to try Defence Force personnel of any rank, or in its power to impose any punishment prescribed by military law. ${ }^{67}$

Irish Courts-Martial always involve a professional judge with sufficient institutional independence, ${ }^{68}$ a defence lawyer (in most cases), ${ }^{69}$ and a prosecutor acting on behalf of the independent Director of Military Prosecutions. ${ }^{70}$ Furthermore, all courts-martial can give rise

Ibid, art 35(2): "All judges shall be independent in the exercise of their judicial functions and subject only to this Constitution and the law."

See for instance, International Covenant on Civil and Political Rights, 16 December 1966, 999 UNTS 171 (entered into force 23 March 1976), art 14(1) [ICCPR]; and see the European Convention for the Protection of Human Rights and Fundamental Freedoms, 213 UNTS. 222 (entered into force 3 September 1953), art 6(1) [ECHR].

Supra note 10.

Defence Act, 2007, supra note 10, s 184L(2).

Ibid, ss 1840, 184P.

Ibid, s 192(1A), (1B).

Ibid, ss 190, 189, respectively.

Ibid, s 198.

Ibid.

Ibid, s 192(2).

For the scale of available punishments, see ibid, s 210.

See ibid, ss 184J-P (describing, among other things, the highly formalized selection criteria, terms of appointment, and removal process for military judges).

Ibid, s 211A.

Ibid, s 184G(4). 
to appeals of both convictions and sentences to the Court-Martial Appeal Court. ${ }^{71}$ In these key respects, as in Canada, courts-martial in Ireland are not particularly vulnerable to criticisms that they are unconstitutional, inconsistent with human rights standards, or otherwise systemically unfair.

The system for summary disposal of charges in Ireland is also similar to the summary trial system in Canada. Trials are conducted by Commanding Officers or other "authorized" or "subordinate" non-judicial officers within the accused person's chain of command. ${ }^{72}$ As in Canada, "the aim of the summary procedure is to deal fairly and swiftly with minor disciplinary infractions within the unit and to return the member to normal service as soon as possible."73 An "assisting person" (who is not required or likely to be a lawyer) ${ }^{74}$ may be present to assist the accused person at a summary hearing but may not participate in the hearing. ${ }^{75}$ There do not appear to be any formal rules of evidence that are binding upon an officer who disposes of a charge summarily. ${ }^{76}$ The Irish Director of Military Prosecutions (DMP) and his prosecutors have no role to play in a summary hearing (although the DMP's consent is required in some circumstances to dispose of a charge summarily). ${ }^{77}$ In all of these ways, despite slight differences in terminology, the Irish and Canadian modes for trying offences summarily within the military justice system are substantially similar.

However, since the Irish Defence (Amendment) Act 2007 came into full force on 21 September 2008, ${ }^{78}$ some significant differences now exist between the Irish and Canadian summary trial systems. In Ireland, there is now a universal right to elect trial by court-martial for all offences, and this right is extended to accused persons of all ranks. ${ }^{79}$ There is similarly a universal right to appeal a decision that is made summarily by a non-judicial officer to a SCM (recall that a SCM is a judicial court with a traditional measure of judicial independence). ${ }^{80}$ Appeals from summary hearings shall take place by way of a rehearing of the charge and, if necessary, the sentence. ${ }^{81}$ Finally, the power of a Commanding Officer to impose punishments of detention for up to 28 days that previously existed in the Defence Act,

$71 \quad$ See Courts-Martial Appeals Act, 1983, No 19 of 1983, s 13.

72 See Defence Act, 1954, as amended by the Defence Act, 2007, supra note 10, s 177C (summary disposal by authorized officer); s 178C (summary disposal by Commanding Officer); s 179C (summary disposal by subordinate officer).

73 O’Dea, supra note 9, at column 1538.

$74 \quad$ See Defence Forces Regulation A7, para 77(3), which provides that "no counsel or representative shall appear before the officer conducting the summary investigation except as provided in Rule 10(15) of the Rules. The person being charged may have an assisting person in accordance with paragraph $76 \mathrm{~F}$ of these regulations." Essentially this means that there is a strict prohibition on a person appearing as a lawyer even in a non-participatory capacity except in the scenario as envisaged by Rule 10(15) of the Rules of Procedure (Defence Forces) 2008, SI No 204 of 2008, 11 July 2008 [Rules of Procedure], which "provides for counsel where a person is charged with an offence for which a person would be required on conviction to be sentenced to imprisonment for life."

75 See, for instance, Defence Act, 1954, as amended by the Defence Act, 2007, supra note 10, ss 177C(7)$178 \mathrm{C}(8)$.

76 The Minister for Defence is authorized by virtue of s 184 of the Act (ibid) to make regulations, and, in particular, to make regulations concerning evidence in the investigation and summary disposal of charges (see Rules of Procedure, supra note 76, s 184(1)(a)(iv)). However, no rules of evidence have been set forth in the regulations made under section 184 of the Act.

77 See for instance, Defence Act, 1954, ibid, ss 178C(1) (referring to the requirement for the Director's consent to dispose of charges for certain scheduled offences summarily).

Defence (Amendment) Act 2007 (Commencement) Order 2008, SI No 254 of 2008, 2 July 2008 at para 2.

See Defence Act, 1954, supra note 10, ss 177B(2), 178B(1), 179B(1).

Ibid, s 178E.

Ibid. 
$1954^{82}$ was abolished through the new Defence (Amendment) Act 2007, such that only fines, reductions in pay, reprimands, and other similar minor punishments can now be imposed after summary disposal of a charge. ${ }^{83}$ Each of these three reforms ostensibly represents an expansion of the procedural protections from which an accused person benefits under the Irish military justice system, ${ }^{84}$ beyond any that exist in Canada. However, rather than simply viewing these changes as a reason for Canada to enact similar changes, one might probe more carefully into the matter to examine why such differences in the two laws do, and should, exist.

\section{UNDERSTANDING WHY CANADIAN AND IRISH MILITARY JUSTICE SYSTEMS DIFFER}

The key differences between Irish and Canadian forms of summary proceeding within the respective military justice systems could be summarized as follows: an appeal of a summary trial decision to a court exists in Ireland, but not in Canada; the right to elect trial by courtmartial instead of by summary proceeding exists for all offences in Ireland, but not for all offences in Canada; and, a punishment of detention can be imposed at a summary trial in Canada, but not in Ireland. The next section offers several reasons why these two military justice systems might have recently evolved in such distinct ways. The simplest reason, as will be explained below, is because the two countries are bound by different international human rights instruments, which impose different "fair trial" obligations on party states. If, however, one looks beyond the distinct international legal obligations that bind Canada and Ireland, it becomes apparent that at least one other social phenomenon that is operative in Ireland, but not in Canada, might also explain why each country has, and needs, its own unique military justice system. In particular, some explanation for the differences could be derived from discussions about the labour climate in the Irish Defence Forces, as manifested through the activities of union-like representative associations. Each of these two possible sources of divergence between Irish and Canadian military justice laws will now be explored.

\section{A. INTERNATIONAL HUMAN RIGHTS INFLUENCES ON IRISH AND CANAdian MiLitaRY JUSTICE}

The differences in Canadian and Irish summary trial systems all essentially relate to the procedural protections from which an accused person benefits when facing such trials, and can therefore be discussed within the context of broader fair trial rights under international human rights law (IHRL).

Ibid, s 178(3)(a)(i).

Defence Act 2007, supra note 10, s 25, which sets forth the new s 178C(5) to the Defence Act, 1954).

The amendments were certainly hailed as being for the benefit of accused persons. For instance, the Irish Permanent Defence Force Other Ranks Representative Association (PDFORRA is an association created to represent the interests of non-commissioned personnel on matters regarding pay and conditions of service - similar to a trade union in many respects) suggested that "the introduction of the Defence Amendment Act, improved the lot of the soldier in three distinct areas. New rights were acquired by an accused facing summary disposal.” See PDFORRA, “A Summary of Your Rights in Military Law,” online: <http://www.pdforra.ie/docs/Your-Rights-in-Military-Law.pdf> [“Summary of Your Rights”]. 


\section{IRISH AND CANADIAN COMPLIANCE WITH THE INTERNATIONAL COVENANT ON CIVIL AND POLITICAL RIGHTS}

Both Ireland and Canada are parties to the ICCPR ${ }^{85}$ including the First Optional Protocol to the Convention. ${ }^{86}$ Thus, both countries recognize the ICCPR's article $14(1)$ right that provides that, "[i]n the determination of any criminal charge against him, or of his rights and obligations in a suit at law, everyone shall be entitled to a fair and public hearing by a competent, independent and impartial tribunal established by law," and both countries recognize the competence of the United Nations Human Rights Committee to receive and consider complaints that states have violated any of the rights set forth in the ICCPR. ${ }^{87}$ However, the article 14(1) right is phrased in large and abstract terms, and there remains substantial uncertainty about the scope and meaning of the right. Do "low-level" armed forces disciplinary proceedings such as summary trials in Canada and Ireland amount to determinations of either "criminal charges" or "rights and obligations in a suit at law"? Furthermore, even if article 14(1) applies to such proceedings, then can a commanding officer who adjudicates a matter be considered sufficiently independent and impartial as to satisfy article 14(1)'s requirements?

When considering these questions, the amorphous nature of article 14(1) of the ICCPR becomes apparent. No international court with specialized responsibility for enforcing the ICCPR has ever pronounced on the full meaning of article 14(1), since no such court exists. Although the United Nations Human Rights Committee (HRC) has the responsibility for monitoring the implementation of the Convention, ${ }^{88}$ and it can receive communications (complaints) regarding a state's failure to implement the convention, ${ }^{89}$ the HRC's enabling provisions within the ICCPR seem to create more of a soft dispute resolution mechanism than a court-like adjudicative body. ${ }^{90}$ Thus, it is difficult to argue that the HRC has authority to issue binding orders to states party to the Convention, or that its interpretations of the rights set forth in the ICCPR are infallibly authoritative. ${ }^{91}$ Nonetheless, while recognizing that states might dispute the level of obligation that attaches to opinions of the HRC, it is clear that the HRC has a certain specialized, although not entirely judicial, role to play in the interpretation of the ICCPR. In light of this reality, it is important for the purposes of the

(

\section{Supra note 58.}

Optional Protocol to the International Covenant on Civil and Political Rights, New York, 16 December 1966, 999 UNTS 302, 21 UN GAOR Supp No 16 (entered into force 23 March 1976) [ICCPR-OP1]. Ibid, art 1.

ICCPR, supra note 58, art 40(2). The mandate of the HRC is also described on its UN High Commissioner for Human Rights website: “The Human Rights Committee is a body of independent experts that monitors the implementation of the International Covenant on Civil and Political Rights by state parties” online: Human Rights Committee <http://ohchr.org/EN/HRBodies/CCPR/Pages/CCPR Index.aspx $>$ [HRC Website].

ICCPR, ibid, art 41.

The HRC asserts that its opinions "represent an authoritative determination by the organ established under the Covenant itself charged with the interpretation of that instrument," and that its decisions are binding on states party because of article 2(3)(a) of the ICCPR (see United Nations Human Rights Committee, The Obligations of States Parties under the Optional Protocol to the International Covenant on Civil and Political Rights, CCPR GC No 33, UNC-CPROR, 94th Sess, (5 November 2008) at paras 13-14). Nonetheless, articles 40-42 of the ICCPR seem more concerned with arriving at an "amicable solution" to a complaint by a state party than with issuing directions to states.

In fact, article 4(2) of ICCPR-OP1, supra note 86 , seems to explicitly contemplate the possibility that a state will disregard any suggestion by the HRC that the state has violated an individual's rights: "Within six months [of being notified of a complaint by the HRC], the receiving State shall submit to the Committee written explanations or statements clarifying the matter and the remedy, if any, that may have been taken by that State" [emphasis added]. 
present case study to consider how the HRC views the right to fair trial by an independent and impartial tribunal under article 14(1) of the ICCPR.

The HRC periodically "publishes its interpretation of the content of human rights provisions, known as general comments on thematic issues or its methods of work." 2007, the HRC published General Comment Number 32 (GC 32), “Article 14: Right to Equality Before Courts and Tribunals and to a Fair Trial,"93 which replaced the only other General Comment to deal with article 14 fair trial rights. ${ }^{94}$ While speaking generally about the right to a fair trial in the context of civilian justice systems throughout the world, the HRC made several comments within GC 32 about the right that are relevant to military justice systems.

Most explicitly, GC 32 affirmed that article 14 applies to all courts and tribunals, "whether ordinary or specialized, civilian or military," 95 while suggesting that the trial of civilians in military courts should be exceptional. ${ }^{96}$ Civilians cannot be tried summarily within the Canadian military justice system ${ }^{97}$ nor within the Irish military justice system unless they have elected to be tried in that forum rather than by court-martial..$^{98}$ Furthermore, civilians in each jurisdiction can arguably only be tried by courts-martial under exceptional circumstances, ${ }^{99}$ so the HRC's guidance regarding civilians is probably not problematic for either country. The assertion that article 14 applies to all military tribunals, however, must be further unpacked in order to be properly understood, particularly since the HRC claims, in the same GC 32, that article 14 will not apply to certain military disciplinary proceedings:

[T]here is no determination of rights and obligations in a suit at law where the persons concerned are confronted with measures taken against them in their capacity as persons subordinated to a high degree of administrative control, such as disciplinary measures not amounting to penal sanctions being taken against a civil servant, a member of the armed forces, or a prisoner. ${ }^{100}$

In other words, if the types of punishments imposed at military summary trials do not amount to truly penal sanctions, then article 14 of the ICCPR would not apply at all to these trials.

Human Rights Committee, “Introduction,” online: Office of the High Commissioner for Human Rights $<$ http://www.ohchr.org/EN/Pages/WelcomePage.aspx >.

United Nations Human Rights Committee, Article 14: Right to Equality Before Courts and Tribunals and to a Fair Trial, CCPR GC No 32, UNCCPROR, 90the Sess, (23 August 2007) [GC 32].

Ibid at para 1. GC 32 superseded the previous GC 13 (United Nations Human Rights Committee, Article 14: Equality Before the Courts and the Right to a Fair and Public Hearing by an Independent Court Established by Law, CCPR GC No 14, UNCCPROR, 21st Sess, (13 April 1984)).

GC 32, ibid at para 22.

Ibid.

Sections 163(1)(a) and 164(1)(a) of the NDA, supra note 7, prescribe the classes of people who can be tried by Canadian summary trials, and the list does not include civilians.

Defence Act, 1954, as amended, supra note 10, s 121(b).

Section 60 of the Canadian NDA, supra note 7, lists the classes of people who could be tried by courts martial. Only civilians with a clear connection to the military (such as civilians who accompany a unit or element of the Canadian Forces that is on active service somewhere) would be liable to be tried by courts martial, arguably to their benefit so that Canadian instead of a foreign criminal process would apply to them while outside of Canada. Similar provisions exist within the Irish Defence Act, 1954, as amended by the Defence Act, 2007, supra note 10, ss 118-19.

GC 32, supra note 93 at para 17 [footnotes omitted] [emphasis added]. 
Where punishments of detention cannot be imposed through summary disposal of charges in Ireland, one could reasonably conclude that these summary proceedings are outside of the scope of the ICCPR's fair trial guarantees. However, the possibility of detention as a punishment at summary trials in Canada does not necessarily mean that ICCPR article 14 applies. The punishment of detention in Canada has a uniquely rehabilitative focus that is distinct from criminal sentences of imprisonment: detention "seeks to rehabilitate service detainees, by re-instilling in them the habit of obedience in a structured, military setting, through a regime of training that emphasizes the institutional values and skills that distinguish the Canadian Forces member from other members of society."101 In this sense, detention — at least for ICCPR purposes — might be conceptualized more as a return to basic military training than as a penal form of imprisonment. Therefore, if the punishment of detention that presiding officers can impose at Canadian summary trials is not a "penal sanction" — but rather a rehabilitative disciplinary sanction — then both Canadian and Irish forms of summary trials would be beyond the scope of the ICCPR's article 14 .

Even if detention or some other punishment that could be imposed through summary trials in Ireland or Canada were deemed "penal sanctions" so as to trigger the application of article 14 of the ICCPR, one must still determine whether trials by members of an accused person's chain of command run afoul of the "independent and impartial tribunal" guarantee that article 14 provides. On this point, the HRC offers the following guidance:

The notion of a "tribunal" in article 14, paragraph 1 designates a body, regardless of its denomination, that is established by law, is independent of the executive and legislative branches of government or enjoys in specific cases judicial independence in deciding legal matters in proceedings that are judicial in nature. ${ }^{102}$

As this observation indicates, article 14(1) of the ICCPR does not require officers who preside at summary trials on an ad hoc basis to have the same kind of permanent independence from the executive and legislative branches of government that would be required of tenured sitting judges in a civilian criminal justice system. Rather, GC 32 recognizes that article 14(1) will be satisfied if a sufficient measure of judicial independence is provided to these presiding officers in each specific case that comes before them for adjudication.

In Canada, this judicial independence is provided for within the Queen's Regulations and Orders for the Canadian Forces, which stipulates that "the conduct of the proceedings of a summary trial is the sole responsibility of the officer presiding at the trial and no superior authority shall intervene in the proceedings." 103 It also requires the presiding officer to swear an oath to "administer justice according to law, without partiality, favour or affection."104 Thus, even if article 14(1) applies to lower-level military discipline proceedings (a question that can only be answered after first characterizing summary trials as either penal or 
disciplinary matters), then the HRC's guidance still seems to suggest that Canadian summary trials ${ }^{105}$ are consistent with article 14(1)'s demands.

The above discussion about article 14(1) of the ICCPR is useful for two reasons: first, it provides an analysis of how two national forms of military summary trials likely comply with the ICCPR's fair trial guarantee, and, second, it offers a necessary frame of reference for the ensuing discussion of the fair trial guarantee contained within the $E C H R^{106}$ that applies to the Irish, but not Canadian, military justice system. As will become evident, the manner in which two similarly-worded fair trial rights (that is, article 14(1) of the ICCPR and article 6(1) of the $E C H R$ ) are interpreted can fundamentally affect the demands that are placed on party states if they intend to comply with their international obligations.

\section{THE HEAVy HaND OF THE EUROPEAN COURT OF HuMAN Rights: IRELAND'S ADDITIONAL IHRL OBLIGATIONS}

Ireland is one of the original parties to the ECHR that came into force in 1953, and Ireland's commitment to the implementation of the Convention was unequivocally manifested in the enactment of the domestic European Convention on Human Rights Act 2003. ${ }^{107}$ Regardless of how much or little impact the ECHR may have previously had upon the law in Ireland, the ECHR Act 2003 forced both the courts and "every organ of the State" (including the Oireachtas, the Irish Parliament) to perform its functions "in a manner compatible with the State's obligations under the Convention provisions." 108 So, in order for Ireland to respect its IHRL obligations as a matter of both international and domestic law, ${ }^{109}$ the Irish military justice system's mechanism for summary disposal of charges must be consistent with the ECHR (and not only the ICCPR) right to a fair trial.

Unlike the ICCPR right to a fair trial, however, the $E C H R$ version of the right ${ }^{110}$ has a well-established content that has been articulated in numerous decisions, ${ }^{111}$ including decisions that deal specifically with military tribunals, ${ }^{112}$ by the European Court of Human

Although officers who dispose of charges summarily in Ireland may also be provided with similar independence as a matter of policy or practice, there are no equivalent legislative or regulatory provisions within Irish defence law.

106 ECHR, supra note 58.

107 European Convention on Human Rights Act 2003, No 20 of 2003, 30 June 2003 [ECHR Act 2003].

$08 \quad$ Ibid, ss 2(1), 3(1).

109 If Ireland fails to meet its ECHR obligations, then remedies are potentially available to a claimant under both domestic law (see ECHR Act 2003, ibid, s 5, providing for remedies of declarations of incompatibility by Irish courts), and under international law (see ECHR, supra note 58, arts 34, 41 as amended by Protocol 11 to the Convention - allowing individuals to make applications to the European Court of Human Rights (ECtHR), and allowing the court to "afford just satisfaction”).

See ECHR, ibid, art 6(1): "In the determination of his civil rights and obligations or of any criminal charge against him, everyone is entitled to a fair and public hearing within a reasonable time by an independent and impartial tribunal established by law."

111 As of 17 April 2013, the ECtHR decisions database indicates that the article 6 right to a fair trial has factored into 20,991 decisions of the Chamber or Grand Chamber of the Court. The database is online: <http://hudoc.echr.coe.int/sites/eng/Pages/search.aspx\#\{\%22article\%22:[\%226\%22],\%22kpthesauru s\%22:[\%22445\%22],\%22documentcollectionid2\%22:[\%22GRANDCHAMBER\%22,\%22CHAMB $\mathrm{ER} \% 22]\}>$.

112 See for instance, Findlay $v$ UK (1997), 24 EHRR 221 at paras 70-80 [Findlay], where the Court held that a British Army court-martial was not a trial by an independent and impartial tribunal because the Convening Officer - a superior within Findlay's chain of command - who appointed the triers of fact was superior in rank to all of these court-martial members, supervised some of them directly, and ultimately had the power to confirm or vary aspects of the court-martial's decision. See also Grieves $v$ UK (2003), ECHR 683 for a similar finding that British Naval courts-martial lack independence and 
Rights (ECtHR). Without listing all of the extensive content of the right to a fair trial that has been found under article 6(1) of the ECHR, some discussion of the ECtHR's seminal Thompson $v$. $U K^{113}$ case is necessary in order to understand how military summary proceedings must be structured in Europe in order to comply with regional European human rights law.

Lance Corporal Thompson was serving in the British Army in $1996 .{ }^{114}$ In December of that year, he went missing from his unit, and was ultimately arrested by civilian police and returned to his unit where he faced a charge of being absent without leave (AWOL). ${ }^{115}$ There is some dispute about whether Thompson ever elected to be tried by summary trial: at the ECtHR, he maintained that he had never been offered an election to be tried by court-martial, but the UK government claimed that an election was offered to Thompson before his summary trial. ${ }^{116}$ In any event, Thompson was eventually tried by his Commanding Officer at a summary trial on 13 February $1997 .{ }^{117}$ He pleaded guilty to the AWOL charge, and was sentenced to 28 days detention. ${ }^{118}$ Thompson then complained to the European Commission of Human Rights ${ }^{119}$ on 16 May 1997, that, among other things, he was subjected to an unfair trial contrary to article 6(1) of the ECHR, because the summary trial presided over by his Commanding Officer was not an independent and impartial tribunal. ${ }^{120}$

At the time of Thompson's trial, British law provided for summary trials that were, in many respects, the same as present-day Canadian summary trials and Irish summary proceedings prior to the enactment of the Defence (Amendment) Act 2007: an election to be tried by court-martial needed to be offered to an accused person in any case before detention could be imposed as a punishment, but not in cases where more minor punishments would have been appropriate; ${ }^{121}$ Commanding Officers could impose up to 28 days detention - or 60 days detention in exceptional circumstances - as punishment at summary trials; ${ }^{122}$ and, there was no right of appeal to a court from a decision made by summary trial, although superior military authorities could review the decision, and could alter the finding or punishment. ${ }^{123}$

As the ECtHR's decision in Thompson makes clear, these features of a military summary trial are wholly inconsistent with article 6(1) of the ECHR. The ECtHR began by noting that

impartiality due to the role played by members of the chain of command in the proceedings. However, see Cooper v UK (2004), 39 EHRR 8, for a finding that British Air Force courts-martial are independent and impartial tribunals, largely because of the role played by the civilian Judge Advocate and civilian Judge Advocate General in the trial process.

Thompson v UK (2005), 40 EHRR 11 [Thompson].

Ibid at paras 9-10.

Ibid at paras 11-13.

Ibid at para 14.

Ibid at para 13.

Ibid.

The European Commission of Human Rights originally played a screening role with respect to applications received under the ECHR (see, ECHR, supra note 58, art 25), and was responsible for referring appropriate cases to the ECtHR. However, the Commission's role was eliminated through Protocol 11 to the Convention, which came into force on 1 November 1998 (Protocol No 11 to the Convention for the Protection of Human Rights and Fundamental Freedoms, restructuring the control machinery established thereby, 1 November 1998, ETS No 5). All applications before the Commission on that date, including Thompson's application, were then transferred to the ECtHR for consideration. Thompson, supra note 113 at paras 38, 41 .

Ibid at para 22.

Ibid at para 24.

Ibid at para 28. 
the right to a fair trial was engaged in Thompson's case because he faced a sentence of up to 60 days detention, which brought the offence into the realm of "criminal" charges that are contemplated by article 6(1). ${ }^{124}$

The Court then clarified that, even if Thompson elected to be tried by summary trial, such an election could not amount to a waiver of his right to a fair trial for four reasons: ${ }^{125}$ first, Thompson would likely have been influenced by the fact that it was his Commanding Officer — a direct superior - who was offering him the election; second, Thompson would likely have been influenced by the much lighter maximum punishment that a summary trial could impose on him as compared to the maximum court-martial; third, the court-martial system in place at the time as an alternative to summary trial was also unfair from an ECHR article 6(1) perspective; ${ }^{126}$ and, fourth, Thompson was not afforded sufficient opportunity to consult with counsel about any election that might have been offered to him. All of these factors, the ECtHR reasoned, would have perverted any "free and unambiguous" 127 election to be tried by court-martial that may have been offered to Thompson, so even if an election to be tried summarily was made, it could not amount to a waiver of Thompson's right to a fair trial.

Finally, on the substance of Thompson's complaint that his Commanding Officer was not an independent and impartial tribunal, the ECtHR ruled in Thompson's favour:

Most fundamentally, the Commanding Officer was central to the prosecution of the charge against the applicant ... and, at the same time, he was the sole judge in the case. In such circumstances, the Court finds that the summary trial presented even clearer structural independence and impartiality problems than those established in the above-cited Findlay case. ${ }^{128}$

In other words, if British Army courts-martial were incompatible with ECHR article 6(1) due to the influence that members of the chain of command could have upon the prosecution (as found by the ECtHR in Findlay), ${ }^{129}$ then summary trials were even more incompatible with the right to a fair trial by an independent and impartial tribunal. At Thompson's summary trial, his Commanding Officer could do much more than just influence the outcome of the case; as the presiding officer, his Commanding Officer was actually the sole arbiter of the outcome of the case. As a result, the ECtHR found that British law violated article 6(1) of the ECHR, but the Court refrained from ordering damages against the UK, and considered that the "judgment in itself constitutes sufficient just satisfaction" for the applicant, Thompson. ${ }^{130}$

As the Thompson case demonstrates, the ECtHR views a state's obligations under article 6(1) of the ECHR to provide fair trials by independent and impartial tribunals as being much more onerous than the parallel obligations on states that have been described by the HRC in relation to article 14(1) of the ICCPR. The important difference between interpretations of

The full explanation of why an election to be tried by summary trial cannot serve to waive one's right to a fair trial under the ECHR is contained at ibid at paras 43-45.

On this point, see the discussion of Findlay, supra note 112.

Thompson, supra note 113 at para 44 .

Ibid at para 46.

Supra note 112.

Supra note 113 at para 52. 
these similarly worded rights is often overlooked by commentators who advocate for a universally expansive right to fair trial in all proceedings. ${ }^{131}$ Thus, when faced with calls for law reform based on developments in European human rights law, stakeholders must not forget that the ECHR is only a regional — not a global — human rights treaty; it is a legitimate source of international law, but its obligations cannot bind states that are not party to the treaty.

This consideration of the Thompson case and of the ECtHR's stance toward fair trial rights in the context of military tribunals brings the present discussion back to the question of why there are, and should be, significant differences in the Irish and Canadian military justice systems relating to summary trials. As Ireland's Minister for Defence clearly stated when recommending the Defence (Amendment) 2007 Act to the Irish Senate, that law reform initiative was, above all else, an effort to comply with Ireland's obligations under the ECHR: "Most importantly, in proposing this Bill, I want to ensure the Irish military disciplinary system is fully compliant with modern European and domestic human rights norms."132 Certainly by eliminating the availability of detention as a punishment at summary trials, the Defence (Amendment) 2007 Act rendered Irish law much more likely to be consistent with article $6(1)$ of the $E C H R$, since this change probably removed the summary disposal process from the domain of "criminal" proceedings that are contemplated in article 6(1). The summary disposal regime's compatibility with the European right to a fair trial was likely also bolstered by the offering of a universal right to elect trial by court-martial (since, on more favourable facts than those found in the Thompson case, the ECtHR may one day conclude that an election for summary trial amounts to a waiver of the right to be tried by a more procedurally fair court-martial), and by the provision for appeals to courts-martial of all summary decisions.

In Canada, however, there is no legal requirement to implement the more onerous fair trial obligations that have been articulated by the ECtHR. The raison d'être of Canadian summary trials remains the same: the purpose of these trials "is to provide prompt but fair justice in respect of minor service offences and to contribute to the maintenance of military discipline and efficiency, in Canada and abroad, in time of peace or armed conflict."133 If this purpose cannot be achieved, or cannot be achieved as effectively, by eliminating punishments of detention (which are designed to reinforce the habit of obedience that is at the core of military discipline), then offering greater access to trial by courts martial (which are the more time-consuming of the two forms of service tribunal) in the first instance, or by allowing every summary trial decision to be appealed and re-tried by court martial, would be inappropriate changes in Canada. It is irrelevant that the ECHR would demand such changes

For an example of a comment wherein ECtHR jurisprudence is seemingly (but mistakenly) represented as if it applies directly as both Canadian constitutional law and international law that is binding on Canada, see Michel W. Drapeau, House of Commons Standing Committee on National Defence Meeting, 41st Parl, 1st Sess, No 65 (11 February 2013) at 5:

My opinion is based, among others, primarily on the quite abundant jurisprudence from the European Court of Human Rights. They have said that according to the European Convention on Human Rights, to have a trial of a quasi-criminal or criminal nature whereby you can sentence somebody to a loss of liberty when that individual goes before a tribunal that is not chaired by someone who is legally trained, has no right to counsel, has no transcript, and has no right to appeal is not constitutional. It's the only place in Canada where this exists. 
when Canada is not a party to that treaty and when Canada can justifiably claim that its existing summary trial system meets the fair trial requirements of article 14(1) of the ICCPR — the only relevant international human rights treaty that Canada has ratified.

To be clear, the above analysis of ICCPR and ECHR fair trial obligations is not intended to suggest that Canada's summary trial system is flawless or that the system would not benefit from changes. Rather, the discussion merely attempts to clarify that Canada's summary trial system is compliant with Canada's international legal obligations, which are distinct from Ireland's international legal obligations, in order to propose that Ireland's legislative reforms are not necessarily suitable for transplant into the Canadian military justice system. An entirely different question might ask whether Canada's summary trial system is compliant with Canadian constitutional law (namely the requirement of section 11(d) of the Charter to provide fair trials by independent and impartial tribunals) ${ }^{134}$ It might also explore how this domestic fair trial right is circumscribed by yet another body of jurisprudence ${ }^{135}$ that causes the right to differ from both of the similarly-worded ICCPR and $E C H R$ fair trial rights. A further question might examine whether changes to the Canadian summary trial system, whether grounded in comparative law or not, might be beneficial to Canada as a matter of policy rather than as a matter of law. These questions deserve further study, but they are beyond the scope of the present article.

In any case, the above conclusion that Irish and Canadian military justice systems are different because the international laws applicable to these two countries are also different is perhaps a complete answer to the question that asks why such differences exist, at least from a positivist perspective. However, a more intellectually probing and contextualized approach to the analysis might look beyond just the international legal obligations of each country to enquire whether there are additional factors that may have directly or indirectly exerted influences on the respective military justice systems.

\section{B. IRISH REPRESENTATIVE ASSOCIATIONS AND THEIR LINK TO MILITARY JUSTICE REFORMS}

As suggested above, an additional circumstance that may explain the differences between Irish and Canadian summary trial regimes is the general labour environment in each of the two armed forces. In Ireland, statutorily authorized “representative associations” exist for

134 As noted by Colonel Michael Gibson (deputy judge advocate general of military justice, Office of the Judge Advocate General, Department of National Defence) House of Commons Standing Committee on National Defence Meeting, 41st Parl, 1st Sess, No 66 (13 February 2013) at 15, this question has seemingly been answered in the affirmative by some of Canada's most eminent criminal law jurists, including two former Chief Justices of Canada:

How did they come to that conclusion?... Of course they engaged in a section 1 charter analysis. I have to say that, unfortunately, if one is going to conduct a measured, balanced, and sophisticated assessment of this issue, you have to engage in a section 1 analysis. Having done that, they concluded that although there were certainly concerns about limitations on some charter rights, that on balance those limitations are justified by section 1 , having regard to the pressing and substantial nature of the concerns that then animate the system.

135 See for instance, Reference re Remuneration of Judges of the Provincial Court (PEI), [1997] 3 SCR 3, for the Supreme Court of Canada's description of the extensive measures of independence that are required in order for Canadian judges to meet the constitutional standard that is provided for within section $11(\mathrm{~d})$ of the Charter. 
both non-commissioned members and officers of the Irish Defence Forces (IDF). ${ }^{136}$ Although these associations are explicitly characterized as something other than trade unions, their functions bear remarkable similarities to those of a union: the Permanent Defence Force Other Ranks Representative Association (PDFORRA) claims that its "purpose is to represent and pursue the interests of enlisted personnel serving in the Army, Naval Service and Air Corps, on specified matters regarding their pay and certain conditions of service."137 The Representative Association of Commissioned Officers (RACO) performs a similar function for all but the highest ranks of officers within the Irish Defence Force. ${ }^{138}$ No such organizations exist within the Canadian Forces. The existence of these associations in Ireland can perhaps explain how military justice reforms that tend to be for the benefit of accused persons would be enacted in that country, but not necessarily in other countries where unionlike representative associations are absent from the military landscape.

The history of how representative associations were formed in Ireland is fascinating, particularly for individuals who are more familiar with the Canadian, British, and American militaries, where such organizations - and the very idea of collective industrial action by military members - are completely unknown. Although representative associations for armed forces personnel have existed for some time in Belgium, ${ }^{139}$ Germany, ${ }^{140}$ and Denmark, ${ }^{141}$ and unions for military personnel have similarly existed in the Netherlands ${ }^{142}$ and Austria, ${ }^{143}$ there had been no serious effort to establish any such group in Ireland prior to $1988 .{ }^{144}$ However, as Gannon describes, members of the IDF faced increasingly difficult conditions of service throughout the 1980s as the Irish military was tasked with more (complex and often dangerous) internal security, aid to the civil power, and United Nations operations, ${ }^{145}$ while at the same time they saw their salaries decrease in both real and comparative terms. ${ }^{146}$ This situation began to occupy the public's consciousness in early 1988, when news stories were released about soldiers who felt forced to collect welfare benefits because of their insufficient salaries. ${ }^{147}$

In the months following these initial news stories, change unfolded extremely quickly. Wives of service personnel formed a vocal activist group called the National Army Spouses Association (NASA) and picketed Parliament while lobbying for better pay, ${ }^{148}$ the IDF Chaplains collectively expressed their concerns about declining morale and the sense of injustice permeating the ranks of the IDF to the Chief of Staff, ${ }^{149}$ and the Chief of Staff

See Irish Defence (Amendment) Act 1990, No 6 of 1990, s 2 (allowing the Minister for Defence to make regulations for the establishment of representative associations) [Defence Act 1990], and Defence Force Regulation S6, 16 May 1991, permitting the establishment of representative associations.

Permanent Defence Force Other Ranks Representative Association, “Welcome to Our Website,” online: $<$ http://www.pdforra.ie/>.

Representative Association of Commissioned Officers, “Home,” online: <http://www.raco.ie/>. Michael P Gannon, The Advent of Representative Associations in the Irish Defence Forces, (MMAS Thesis, United States Army Command and General Staff College, 1992) at 21-22. Ibid at 22-23.

Ibid at 28-29.

Ibid at 25-27.

Ibid at 27-28.

Ibid at 85-86.

See generally, ibid at 51-57.

Ibid at 60-72.

Ibid at 85 .

Ibid at 91-92.

Ibid at 87. 
formed an advisory group to make submissions to a government committee on IDF pay and allowances. ${ }^{150}$ However, at the same time, and in response to initial suggestions that representative associations for the IDF be formed, the Chief of Staff publicly expressed a conviction that "the establishment of a representative body or a trade union would be entirely inappropriate.” 151 Ultimately, the government committee on pay and allowances recommended only a nominal pay increase, ${ }^{152}$ which fuelled rumours of mass resignations within the IDF. ${ }^{153}$ As Gannon observes, "representation now seemed to be the only option left whereby the Defence Forces personnel could achieve what they perceived as a fair rate of pay and appropriate conditions of service.”154

In the next general election that took place in June 1989, several former NASA members ran for office while continuing to advocate for IDF personnel, and one of these candidates is credited with unseating a government incumbent. ${ }^{155}$ After the election, the Fianna Fail government lost its majority status and formed a coalition government. ${ }^{156}$ As part of the change, a new Minister for Defence was appointed, and this Minister seemed more receptive to the idea of representative associations, notwithstanding the opposition to them expressed by senior military leaders. ${ }^{157}$ Meanwhile PDFORRA was created, and it began a form of unofficial representation of IDF non-commissioned members. ${ }^{158}$ In February of 1990, the Secretary of PDFORRA gave an interview on Irish radio and a press conference at Dublin airport and was subsequently threatened by his Company Commander with charges for giving unauthorized interviews contrary to Defence Force Regulations, although no charges were ever laid. ${ }^{159}$ Tensions began to abate shortly thereafter; RACO was formed, and by May of 1990, the Chief of Staff had "acknowledged the right of officers to set up their own association.”160 By May of 1991, this right of both non-commissioned members and officers to be represented was enshrined in statute and regulations, ${ }^{161}$ thereby legitimizing the activities of the already-operating representative associations.

Since the formation of RACO and PDFORRA, the associations have periodically been quite active in lobbying for their members. For instance, when the Irish Congress of Trade Unions (ICTU) generally began to mobilize in 2009 against public sector pay cuts, and when an alliance of emergency services unions (representing nurses, prison workers, and firefighters) specifically began to campaign against these cuts, PDFORRA publicly joined the

Ibid at 88-91.

Ibid at 91. The Chief of Staff's opposition to representative associations is easy to understand, given his position as the senior military officer of the IDF, since the concept of collective labour action within an armed force can approach very closely to mutiny. For a more contemporary expression of the unease that industrial relations concepts bring to those associated with leadership and management of an armed force, see the February 2009 remarks of Irish Minister for Defence Willie O’Dea, in response to a parliamentary question about whether an IDF representative associations should be permitted to join the Irish Congress of Trade Unions, Dáil Éireann Debate, Vol 673, No 3 (4 February 2009) at 12, online: Houses of the Oireachtas <http://debates.oireachtas.ie/dail/2009/02/04/00012.asp>. Gannon, ibid at 93-94.

Ibid at 95 .

Ibid.

Ibid at 97.

Ibid at 97-98.

Ibid at 98-101.

Ibid at 101 .

Ibid at 101-102.

Ibid at 103.

Defence Act 1990, supra note 136, s 2 (allowing the Minister for Defence to make regulations for the establishment of representative associations), and Defence Force Regulation S6, supra note 136 (permitting the establishment of representative associations). 
alliance in order to advocate against cuts to pay and allowances for its military members. ${ }^{162}$ PDFORRA was similarly vocal in the association's objections to closures of defence establishments throughout Ireland - much to the displeasure of the government of the day. ${ }^{163}$ This type of direct and collective challenge to government policies by members of the armed forces would be outright unlawful in Canada by virtue of multiple articles of Queen's Regulations and Orders for the Canadian Forces, ${ }^{164}$ but it serves as an excellent example of how fundamentally different the relationship between individual military members and their government is in Ireland and Canada, respectively.

With a better understanding of how labour and industrial relations influences have penetrated the IDF, but not the Canadian Forces, it is now possible to consider how this factor may have contributed to divergent trends in the military justice systems of the two countries. In Canada, no collective group with an exclusive function of representing the interests of officers or non-commissioned members exists, so it seems unlikely that reforms to the military justice system would have been made solely for the benefit of military subgroups, as opposed to for the benefit of the institution of the Canadian Forces as a whole. In Ireland, however, the lobbying that is performed by RACO and PDFORRA on matters of pay and conditions of service might easily have directly or indirectly influenced the character of Irish military justice in a way that has led to greater individual rights being conferred on accused persons (such as the right to elect court martial for any offence, to appeal summary disposal decisions, or to benefit from only non-custodial punishments). Clearly, a representative association that is concerned with the pay and conditions of service of IDF members will also be concerned about other ways in which the armed forces can affect or encroach upon members' liberties.

The political importance of the two representative associations in law reform processes was acknowledged by the Irish Minister for Defence when he noted, in relation to the Defence (Amendment) Act 2007, that "both RACO and PDFORRA have been fully briefed

See Permanent Defence Force Other Ranks Representative Association, "PDFORRA Denied Right to Represent its Members,” 30 September 2009, online: <http://pdforra.ie/news/?p=282> for a description of the initial government response to PDFORRA's efforts, and Permanent Defence Force Other Ranks Representative Association, "We will not be silenced in our efforts to represent our members" (12 October 2009), online: <http://pdforra.ie/news/?p=292> for a summary of PDFORRA's refusal to acquiesce to government pressure.

163 It should be noted that Defence Forces Regulation S6, supra note 136, Section II, expressly provides that "the Association shall not sponsor or resort to any form of public agitation as a means of furthering claims or for any purpose whatsoever." However, the government has, on several occasions, found it necessary to condemn some of the more active forms of representation by PDFORRA. See, for instance, the response by Minister for Defence Willie O’Dea to a written question in Parliament, Dáil Éireann Debate, Vol 668, No 4 (26 November 2008) at 956, online: Houses of the Oireachtas <http://debates. oireachtas.ie/dail/2008/11/26/00030.asp>:

My Department has an obligation to seek to ensure that the representative process operates in accordance with the relevant legislation and in the best interests of the parties to the process. In meeting this obligation, my Department has correctly expressed concern to PDFORRA about specific actions taken by them that could damage the system of representation in the long term. I have also expressed my disappointment to PDFORRA in this regard. I am aware of the views of PDFORRA on the decision to close these barracks. This does not, however, confer a right on PDOFRRA to depart from the scope of representation as enacted by the Oireachtas.

$Q R \& O$, supra note 35, art 19.10, for instance, forbids officers and non-commissioned members from petitioning in relation to the Canadian Forces, and from combining in order to effect changes to regulations for the Canadian Forces. Similarly, $Q R \& O$, article 19.36 prohibits personnel from publicly communicating their opinions on military matters without permission of the Chief of the Defence Staff. 
on the contents of the Bill and have welcomed the measures contained therein."165 There is no evidence to suggest that either representative association was actually involved in the drafting of the Bill. However, it would strain credulity to suggest that the law was created without consideration having been given to the potential reactions of PDFORRA and RACO to the reforms, or that either of these associations would have quietly accepted changes to the military justice system that were less favourable to accused persons. PDFORRA, for instance, adverted to its dissatisfaction with the pre-2007 military justice system by noting in an information circular for its members that, "the introduction of the Defence Amendment Act, improved the lot of the soldier in three distinct areas."166 As this statement indicates, a representative association was, at a minimum, tracking and publicly commenting upon developments in Irish military law that tended to affect the conditions of service of its members.

Ultimately, the magnitude of any impact that Irish representational associations may have had on military law reform is difficult to ascertain. However, as the above discussion demonstrates, the presence of such union-like entities in Ireland has surely contributed to the development of a summary disposal disciplinary process that is more favourable to accused persons than in the past. The history of Irish representational associations reveals that they were borne of a widespread dissatisfaction amongst military members with the administration and governance of the IDF and that these groups were eventually legitimized in 1990 by the government of the day, against the advice of military leadership. ${ }^{167}$ In Canada, approaches to leadership and administration of the Canadian Forces over the last 50 years have been such that large-scale mobilizations of military members against government policies have not taken place. Chris Madsen, Canada’s leading scholar in the field of military legal history, notes that a

movement toward military unionism, as in the United States, has yet to gain much traction in Canada due to a combination of statutory-based exemption, prevailing attitudes inside and outside the all volunteer professional military and, at times, outright aversion to the idea by senior military leadership. ${ }^{168}$

Consequently, in spite of periodic suggestions in favour of unionization, ${ }^{169}$ there has never been the same (or any significant) pressure to unionize or create representative associations within the Canadian Forces as there was in the IDF.

Since the labour environments in the Irish and Canadian armed forces are so different in this respect, any argument that fails to acknowledge and explain these differences while still suggesting that Canada should parallel changes to Irish military law loses some persuasive effect. Ireland appears to have permitted the formation of representative associations in 1990

O’Dea, supra note 9 at column 1541.

PDFORRA, "Summary of Your Rights," supra note 84.

See Gannon, supra note 139 at 91, quoting the Chief of Staff's statement in 1988 that "the establishment of a representative body or a trade union would be entirely inappropriate" and at 102, noting that the Minister agreed to PDFORRA's terms in 1990, and that "the General Staff were scarcely consulted on this move by the Minister."

Chris Madsen, Military Law and Operations, vol 1 (Aurora: Canada Law Book, 2010) at 4-6-4-7 [footnote omitted].

169 Ibid at 4-8-4-10, describing calls for military unionization that took place from outside of the Canadian Forces in 1970, and a suggestion in Canadian Forces Command and Staff College research paper in 1996 that the time for a collective bargaining association may have arrived. 
as a concession to an increasingly disgruntled military population, rather than out of a desire to better serve the institutional needs of the IDF. In Canada, where no such pressure to accept military unions or representative associations exist, the government is free to develop law and policy for the benefit of the armed forces as a whole, rather than for the benefit of a strictly self-interested sub-group. In other words, Canada's military justice system can develop in ways that best serve the interests of discipline, efficiency, and morale of the force, ${ }^{170}$ without any one of those interests subverting the others. If Irish reforms to the summary disposal process such as those enacted in the Defence (Amendment) Act 2007 clearly contribute to an increase in morale for personnel who benefit from new procedural protections, but do not yield a net increase to the interests of discipline, efficiency, and morale within the armed forces, then they would be inappropriate for adoption in Canada.

Notwithstanding the above discussion, the purpose of this article is not to conclusively prove that Ireland's form of summary proceeding would be inappropriate for transplant to Canada, since such an effort would likely require empirical data about the effect of Irish-style reforms on discipline, efficiency, and morale within the Canadian Forces - data that might be impossible to collect. Instead, this article strives to make the more modest point that what is good for Ireland is not necessarily good for Canada. For example, one can intuitively appreciate that permitting universal appeals of summary trial decisions will hinder the efficiency of an adjudicative system by adding incremental costs (both financial and temporal) associated with the disposition of each appeal, particularly where the appeals are structured as trials de novo, rather than more limited appeals based on the record. Indeed, a majority of the Supreme Court of Canada recognized many of the costs of appeals in the leading decision on the standard of appellate review in Canada, Housen $v$ Nikolaisen, ${ }^{171}$ where the majority articulated a desire to limit "the number, length and cost of appeals,"172 while also "[p]romoting the [a]utonomy and [i]ntegrity of [t]rial [p]roceedings," 173 and "[r]ecognizing the [e]xpertise of the [t]rial [j]udge and [h]is or [h]er [a]dvantageous [p]osition" ${ }^{174}$ as compared to an appellate judge. Thus, while appeals may offer some benefits, they inevitably tend to weaken the overall efficiency of a justice system. In the end, however, the question of whether any Canadian reform package that would include universal appeals, universal elections to be tried by courts martial, and the elimination of detention as an available punishment would provide a net increase or a net loss to discipline, efficiency, and morale remains to be answered another day. The most that can be said, for the time being, is that evidence of such changes having been successful in Ireland is an altogether insufficient basis for adopting the same reforms in Canada.

See Généreux, supra note 51 at 293, for an explanation from the Supreme Court of Canada as to why a separate military justice system must exist: "The purpose of a separate system of military tribunals is to allow the Armed Forces to deal with matters that pertain directly to the discipline, efficiency and morale of the military." 


\section{RE-THINKING THE ROLE OF COMPARATIVE LAW AS A LAW REFORM TOOL}

While the above case study of Irish and Canadian military justice systems makes a very specific point about the potential incompatibility that exists between recent Irish reforms and the current Canadian summary trial regime, it can also illustrate a more general point about the utility of comparative law in the context of law reform initiatives. Parliamentarians and critics of the Canadian military justice system continue to suggest that changes to the summary disposal process in Ireland should serve as a precedent to be followed in Canada, ${ }^{175}$ when careful analysis of the two systems and the broader environments within which they operate reveals that transplantation of Irish ideas into Canadian law would not necessarily be productive. References to comparative law, in this case, can represent a hazard to the principled and coherent evolution of Canadian law, rather than a productive tool through which change can be achieved, particularly if nuances between the comparator and home jurisdictions are not fully explored. As the Irish/Canadian military justice case study suggests, perhaps the time has come for scholars to acknowledge that comparative law must now often be studied in order to deconstruct and defend against popular calls for law reform that are based on developments in other jurisdictions, as well as in order to actively bring about legal change.

In their foundational textbook, An Introduction to Comparative Law, Konrad Zweigert and Hein Kötz suggest that one of the chief functions of comparative law is to serve as a law reform resource. ${ }^{176}$ The authors claim that, in its applied (rather than descriptive) form, comparative law offers scholars access to ideal solutions to domestic legal problems, and they boldly assert that many legislators cannot produce good laws "without the assistance of comparative law." 177 Zweigert and Kötz were probably correct in making this statement when their work was first published in English in 1977, based on assumptions that are surely implicit in the claim. Comparative law at that time was, or at least was attempting to become, a scholarly discipline in its own right ${ }^{178}$ and was therefore practiced by academics. Although one commentator writing at around the same time as Zweigert and Kötz observed that “[ $t$ ]he necessary aids for the study of comparative criminal law are also fully available today in the form of bibliographies, collections of statutes, periodicals, monographs and congressional materials," 179 this assertion must also be understood as meaning that comparative law resources were accessible to scholars and to those with more than just a basic level of research competence, since each of those "necessary aids" would only likely be found within law libraries. In short, at the time when Zweigert and Kötz suggested that comparative law was a valuable law reform resource, the discipline was an academic one rather than a popular

175 Drapeau, “More Questions,” supra note 18; House of Commons Debates, supra note 20.

176 Konrad Zweigert \& Hein Kötz, Introduction to Comparative Law: Volume 1 - The Framework, Tony Weir, trans, 2d ed (Oxford: Clarendon Press, 1987) at 15.

177 Ibid.

178 In many ways, Zweigert and Kötz's book, ibid, reads like a justification for the study of comparative law more than an introduction to the field of comparative law. See for instance, Jonathan Hill, "Comparative Law, Law Reform and Legal Theory” (1989) 9:1 Oxford J Legal Stud 101 at 102: "comparatists have sought to provide justifications for the study of comparative law, sometimes in rather extravagant ways" (citing Zweigert and Kötz as an example of this phenomenon).

179 Hans-Heinrich Gescheck, “The Significance of Comparative Law for Criminal Law Reform” (1982) 5:1 Hastings Int'l \& Comp L Rev 1 at 4-5 [footnote omitted]. 
one, and the tools needed to engage in comparative legal study were most likely to be found in academic libraries rather than in popular media.

Technological changes over the last thirty-five years have dramatically increased one's level of access to foreign legal systems. Websites such as WorldLII have published laws from around the world on the Internet, ${ }^{180}$ while national courts have increasingly published judicial decisions online. ${ }^{181}$ Databases and search engines like Google Books, ${ }^{182}$ Google Scholar, ${ }^{183}$ and the Social Sciences and Research Network (SSRN) ${ }^{184}$ have made secondary sources of books and articles widely available to Internet users from their homes or offices, and have in many ways rendered physical libraries closer to obsolescence. ${ }^{185}$ Finally, the use of computers to access all of these resources through software applications that can digitally search and find data from within pages of text has arguably resulted in an exponential reduction in the time required to conduct research on specific aspects of foreign law.

The cumulative effect of these developments has opened the discipline of comparative law to virtually anyone with a personal, financial, or political interest in foreign laws and law reform, such that a form of comparative law can now be practiced by individuals with no academic training in the field, no concept of methodology, and no long-term reputational concern about the sufficiency of their research as a basis for any of their conclusions that one would expect of a scholar. Thus, contemporary calls for law reform that refer to developments in foreign laws as a reason to effect change domestically can lack the kind of scholarly rigour that they might previously have possessed. These proposals can overlook how a specific feature of a foreign law fits into a larger legal scheme, thereby misunderstanding both the effect of the feature in the foreign system and more importantly its suitability for transplant into the local system. Furthermore, without the benefit of training or any kind of guiding methodology, non-scholarly comparative law reform proposals are perhaps more likely to be voiced without consideration for, or in disregard of, the expansive fabric of social, political and cultural circumstances that are unique to each jurisdiction, and that contribute immensely to legal developments in any particular location. Simply put, the pictures that are presented to decision-makers through some comparative law reform proposals are, at best, blurred and cropped representations of the realties that they purport to describe, regardless of how well-meaning the intent that underlies such proposals might be.

Those who still engage in a more scholarly study of comparative law may now have a new task - namely, critiquing less rigorous forms of comparative work that are relied upon as grounds to change domestic law. This new task is beginning to gain recognition in

World Legal Information Institute. "Free, independent and nn-profit acess to worldwide law,”online: $<$ http://www.worldlii.org/>.

181 See for instance, Supreme Court of Canada, "Judgments of the Supreme Court of Canada," online: $<$ http://scc.lexum.org/decisia-scc-csc/scc-csc/en/nav.do>; see also, Supreme Court of Ireland, "Search Judgments by Year,” online: <http://www.supremecourt.ie/Judgments.nsf>; and see, Southern African Legal Information Institute, "Databases," online: <http://www.saflii.org/content/databases > for a list of databases indexing decisions of Southern African courts, among many other similar resources. Online: Google Books <http://books.google.ca/bkshp?hl=en\&tab=wp>.

Online: Google Scholar <http://scholar.google.ca/schhp?hl=en>.

Online: Social Sciences and Research Network <http://www.ssrn.com>.

See Robert Darnton, "Digitize, Democratize: Libraries and the Future of Books" (2012) 36 Colum-VLA J L \& Arts 1, for a general discussion of the future of a Digital Public Library of America project, and of the impact that Google Books has had on the publishing industry. 
comparative law theory; a more recent text (than Zweigert and Kötz's) noted that "comparison could take the opposite position and act as a corrective to prescriptions for law reform." 186 The present Irish/Canadian case study, looking as it does at international and domestic factors that help to explain the source and rationale for differences in each country's summary trial regime, also demonstrates that careful analysis of comparative-based law reform proposals can assist in revealing weaknesses contained within the proposals. The notion that comparative law is needed to defend against unprincipled developments in the law based on flawed comparisons with foreign jurisdictions is starting to gain traction and should not be ignored.

\section{Conclusion}

The value that study of foreign law can bring to discussions about domestic law reform should not be understated, and Zweigert and Kötz are clearly correct when they suggest that comparative law offers "a greater variety of solutions [to domestic problems] than could be thought up in a lifetime by even the most imaginative jurist who was corralled in his own system." ${ }^{187}$ However, in an information age where anyone with an interest can easily access elements of foreign laws and advocate for local change on the basis of such foreign laws, the role of many comparative law scholars must change. The intellectual landscape has now shifted such that there is a surplus of comparative law reform ideas being proffered, but arguably a shortage of capable academic quality control inspectors to evaluate the merits of these proposals. As a result, responsible use of comparative law will now often require scholars to defend against unprincipled transplantation of foreign laws into domestic legal regimes by exposing the weaknesses in law reform proposals, by providing legislators and policy-makers with a better understanding of the larger environments within which foreign laws operate, and by generally correcting for the effect of comparative law's popularization.

In the specific case of Canadian military justice law reforms, a comprehensive comparison of the Irish and Canadian summary trial regimes demonstrates exactly why a comparative law reform shield must be deployed. The Irish and Canadian systems are different, to be sure, and keeping up with the common law Joneses might offer one reason for changing the Canadian system. But it is only one reason, and a not particularly compelling one; it is the kind of reason that could equally lead Canada to abandon unanimous court martial panel verdicts in favour of two-third majority verdicts (to match the Irish system), ${ }^{188}$ or to erode the current constitutional right to silence by permitting fact-finders to draw adverse inferences in situations where an accused person exercises the right to remain silent (as is permitted in Ireland). ${ }^{189}$ Most scholars would agree that changes such as these should be justifiable on their own terms, rather than simply adopted because of their regional popularity elsewhere. Publishing, 2012) at 332 [emphasis added].

Supra note 176 at 15.

Defence Act, 1954, supra note 10, s 198.

See for instance, Criminal Justice Act, 1984, No 22 of 1984, as amended by Criminal Justice Act 2007, No 29 of 2007, ss 18, 19, 19A permitting courts to draw adverse inferences from a suspect's exercise of the right to silence in a wide variety of circumstances in Ireland. For an insightful analysis of the impact and effect of this legislation, see Yvonne Daly, "Is Silence Golden? The Legislative and Judicial Treatment of Pre-Trial Silence in Ireland” (2009) 31 Dublin ULJ 35. 
Is a different kind of thinking somehow required when considering military justice law reforms?

Careful scrutiny of the Irish and Canadian military justice systems and each of their home environments reveals why they are, and perhaps should be, different: Ireland and Canada are bound by different bodies of international treaty law, they have evolved from different historical circumstances, and their armed forces continue to reflect significantly different labour and industrial relations mentalities. If Canada adopted the changes that were made in Ireland through the Defence (Amendment) 2007 Act, then many compromises that have not yet been justified on grounds of discipline, efficiency, and morale would be made (to a system that exists for the dominant purpose of fostering these values) just so that Canadian law could better suit Ireland's realities. Although the fallacy of such a notion is obvious, it is only through the work of responsible comparative law scholars who draw out the similarities and differences between laws and legal systems that such fallacies can be plainly exposed in the first place. 